The Review of Finance and Banking

print ISSN 2067-2713, online ISSN 2067-3825

Volume 12, Issue 2, Year 2020

http://dx.doi.org/10.24818/rfb.20.12.02.04, Pages 155-174

\title{
PRINCIPAL FACTORS MEASURING SERVICE QUALITY: A STUDY OF SELECTED BANKS IN INDIA
}

\author{
VAISHALI PAGARIA
}

\begin{abstract}
Several studies have revealed that there is a relationship between the quality of service offered by the service provider and the level of satisfaction among their customers. But as we know that service quality from the customer's perspective is very subjective. Therefore, service quality dimensions cannot be generalized for all types of services. Though the SERVQUAL model of measuring service quality has proven its applicability across all services, there is a need to have sector-specific Service Quality Management (SQM) Model. This paper attempts to find out the SQM model for the Indian banking sector covering public, private and foreign banks. Principal factors of banking service quality have been identified which are important for customer satisfaction in a particular type of bank.
\end{abstract}

\section{INTRODUCTION}

The banking industry being in the service industry is becoming the primary source of wealth, trade, and economic growth across all the countries. Recent tendencies in globalization and privatization are confronting the banking sector with new challenges and causing an urgent need for the design and development of management concepts and techniques specifically geared to the banking service. Achieving competitive advantages in banking service requires the integration of service quality with service delivery to meet or exceed customer requirements. Customers are an important aspect of bank and loyal consumers can add value to the profitability of banks. Banks must focus on identifying and implementing that service quality factor which contributes to customer satisfaction.

Therefore, the present study focuses to find out the principal factor for measuring service quality from the customer's perspective which affects customer satisfaction in Public, Private and Foreign Banks of India using eight dimensions SQM. Specific objectives are stated as below:

- To understand service quality, its dimensions and derive hypothetical SQM for banks

- To measure customer satisfaction on the service quality attributes of the SQM model for each type of bank.

- $\quad$ To find out principal factors measuring service quality for each bank.

\section{Literature REVieW}

Though too many businesses still think quality in terms of manufactured goods only, the time has come that the management must see the quality in terms of service. In the book 'Out of the Crisis' author W. Edwards Deming observes that there is no distinction between quality practices in manufacturing and service industries. Many studies have derived various dimensions, techniques and organizational requirements for effective implementations quality management practices are mainly for manufacturing industries, but they are not the complete

Received by the editors May 29, 2020. Accepted by the editors October 25, 2020.

Keywords: Banks, Principal Factors, Service Quality Management, Customer Satisfaction.

JEL Classification: G2, G4, G210.

Vaishali Pagaria, PhD, RAssociate Professor, Department of Business Management, Malla Reddy College of Engineering and Technology, Hyderabad, India. E-mail: vaishalipagaria@gmail.com.

This paper is in final form and no version of it will be submitted for publication elsewhere. 
yardstick for service quality improvement. The logic here is that the transferability of manufacturing quality management dimensions to services calls for some serious soul-searching as services differ from the manufactured goods. Unlike the quality of goods, which may be tangible and measured objectively by using indicators such as performance, features, reliability, etc, service quality, however, is not tangible and is thus defined in terms of attitude, interaction, and perception. Thus, service quality is judged by what a customer perceives rather than what a provider offers. The main argument is that the customer's satisfaction is subjective and transaction-specific while perceived service quality is a universal judgment or attitude to service. Saravana \& Rao, (2007) point out that customer satisfaction is based on the level of service quality delivered by the service providers which is determined by the consumer's cumulative experiences at all of the points of contact with the company. This shows that there is some link between service quality and customer satisfaction which highlights the importance of customer satisfaction when defining quality. Many studies confirm that there is a strong relationship between quality of service and customer satisfaction. But according to Asubonteng et al., (1996) there is no agreement on the exact kind of relationship between the two constructs and points out that most researchers agree that service quality and customer satisfaction have measurable attributes.

In the book "Delivering Quality Service" by Zeithaml et al. (1990), the authors used focus groups of four service sectors: retail banking, credit cards, securities brokerage, and product repair \& maintenance, to determine the criteria used by customers in judging service quality. Ten general criteria or dimensions known as SERVQUAL Model revealed from this study are: tangibles, reliability, responsiveness, competence, courtesy, credibility, security, access, communication, and understanding. In 1988, these determinants reduced to five: tangibles; reliability; responsiveness; service assurance, and empathy in the so-called RATER model. These are tangibles, reliability, responsiveness, assurance, and empathy. Shahin et al., (2006) in their study mentioned that this model is the best way to measure service quality as it takes into account customer's expectations of service as well as the perception of the service. The same is supported by Chingang Nde Daniel \& Lukong Paul Berinyu (2010) in their empirical study to assess service quality and customer satisfaction of grocery stores in Umea using the SERVQUAL Model. S. Santhana Jeyalakshmi and Dr. S. Meenakumar (2016) conducted a literature review on the SQM models and concluded that the adoption of SQM models as a tool of measurement suggests that service standards and compliance strategies are especially critical for the service industry to ensure customer satisfaction. Sabrina Tazreen (2012) has applied the SERVQUAL model in the randomly selected bunch of customers regarding the service quality provided by a particular commercial bank in Chittagong and concluded that this model is the best suited to measure service quality with necessary modifications for the service sector. Therefore, the highly subjective concept of service quality not only confines to the realms of elements suggested in SERVQUAL but also encompasses other critical factors, such as the service product or the core service, systematization/standardization of service delivery, and the social responsibility of the service organization. Therefore, the Service Quality Management (SQM) model must have the following eight dimensions (Figure I).

- $\quad$ Tangibles

- Reliability

- $\quad$ Responsiveness

- Assurance

- $\quad$ Empathy

- $\quad$ Service product

- $\quad$ Service delivery

- $\quad$ Social responsibility 


\section{Service Quality Management in Banking Sector}

Today, banks are facing challenges like reaching to the rural market, managing human resources, global banking, financial inclusion, customer and employee retention, product differentiation, social and ethical aspects. Customers, whether at the retail or corporate level have always been important for banks, and therefore, customer satisfaction is highly related to service quality as service quality improves the probability of customer satisfaction. Banks now know that delivering quality service to the customer is essential for success and survival in today's global and competitive banking environment. A research study (2003) on 'comparative analysis of cultural, conceptual and practical constraints on quality management implementations' - findings from Australian and Korean banking industries' found significant relationship and path links between perceived service quality, customer satisfaction, and customer loyalty. In India, the banking industry is the largest in the service sector which caters to the needs of the different categories of people. Notably, the service quality of commercial banks tends to play a dominant role in high involvement industries. And therefore, providing the best service quality is viewed as the pre-requisite for the success of service organizations like banks.

\section{Research Methodology}

A self-administered questionnaire has been designed and collected responses from 15 selected banks including 7 public sector banks (PSBs), 5 private sector banks (PvtSBs), and 3 foreign banks (FBs) from twin cities Hyderabad and Secunderabad of Telangana state, India (Table I) The focus of the study has been on the top-performing banks which are having the maximum number of branches in the selected geographic area. The purpose of selecting this segment is to get holistic responses of the people who are aware of traditional as well as modern banking methods. A stratified sampling procedure has been used because it increases the sample's statistical efficiency and provides adequate data for analysing the various subpopulation. Each stratum (i.e. three sectors of banks PSB, PvtSB, and FB) is homogenous internally (in terms of Indian banking system/procedure) and heterogeneous (in terms of registration status) with other strata. The population for convenience of obtaining responses is segregated into several mutually exclusive subpopulations or strata. After a population is divided into appropriate strata, a simple random sample is taken within each stratum. The sampling result then is weighted and combined into appropriate population estimates. Selection of the strata in the form of the different banking sector has been the convenience of obtaining responses.

Responses of the items in the questionnaire were obtained on a five-point Likert scale with anchors 1 - 'Extremely Satisfied' and 5- 'Extremely Dissatisfied'. The customers were asked to mark a number that truly reflects their feelings regarding banking services for all the 68 statements. Total 531 responses covering 15 banks including PSBs (227), PvtSBs (153), and FBs (151) have been obtained. Keeping in mind the infinite population, at $95 \%$ confidence level and 5 confidence intervals, the minimum determined sample size is 384 (using statistical formula). Since the obtained sample size is more than the determined sample size, the sample mean and standard deviation has been used to estimate the population mean and standard deviation. Respondent customers from these selected banks have been chosen using simple random sampling. However due care has been taken to get responses from all age groups, gender, occupation, and frequency of visiting the bank to get unbiased responses.

The internal consistency, which measures the homogeneity or consistency of responses across all the 68 statements, was evaluated using Cronbach's alpha (Coefficient alpha). A reliability coefficient of 0.70 or higher is considered "acceptable". Factor analysis was carried out to identify the latent factors/dimensions of SQM. The Principal Component Analysis (PCA) approach of factor analysis is used to identify a new set of a composite variable or principal variable that are not correlated with each other. The following key statistics have been calculated to apply PCA on the Data. 
i). Kaiser-Meyer-Olkin (KMO): It is a measure of sampling adequacy. It acts as an index to examine the appropriateness of factor analysis. High values between 0.5 and 1.0 indicate factor analysis is appropriate. Values below 0.5 imply that factor analysis may not be appropriate.

ii). Eigen Value: This represents the total variance explained by each factor. In the present study, only variables with Eigenvalue greater than one are retained.

iii). Factor Loading: This is a correlation coefficient between the statements and the factors. Taking the findings of Nithan Zhao (2009) as the base, the loading size cut-off value is set at 0.6 and any factors with Cronbach's alpha less than 0.7 are dropped.

iv). Communalities: The communalities represent estimates of the variance in each variable. In the present study, only variables with Communalities more than 0.6 are retained.

v). Factor Matrix: This contains the factor loadings of all statements on all the factors extracted.

vi). Percentage of Variance: The percentage of the total variance attributed to each factor.

vii). Rotation of Factors: Factor matrix is transformed through rotation into a simpler one that is easier to interpret. It does not affect the percentage of total variance explained. However, the variance explained by the individual factors is redistributed by rotation. The most commonly used method is the varimax rotation procedure. This procedure maximizes the variance of the loadings on each factor, thus minimizing the complexity of the factor.

viii). Interpretation of Factors: It is facilitated by identifying the statements that have large loadings on the same factor. The factor can be interpreted in terms of the statements that load high on it.

\begin{tabular}{|c|l|c|c|c|}
\hline \multicolumn{5}{|c|}{ Table I: Population Framework Defined for Banks to Determine Sample Size } \\
\hline \multicolumn{3}{|c|}{ Number of Banks and Their Branches in Hyderabad and Secunderabad Cities } \\
\hline SN & \multicolumn{1}{|c|}{ Name of Bank } & No. of & Assumed no. of & Total no. \\
\hline & & 1 & 10 & 10 \\
\hline 1 & RBI & 202 & 10 & 2020 \\
\hline 2 & State Bank of India & 6 & 10 & 60 \\
\hline 3 & State Bank of Bikaner \& Jaipur & 141 & 10 & 1410 \\
\hline 4 & State Bank of Hyderabad & 5 & 10 & 50 \\
\hline 5 & State Bank of Patiala & 14 & 10 & 140 \\
\hline 6 & State Bank of Mysore & 9 & 10 & 90 \\
\hline 7 & State Bank of Travancore & 18 & 10 & 180 \\
\hline 8 & Allahabad Bank & 139 & 10 & 1390 \\
\hline 9 & Andhra Bank & 39 & 10 & 390 \\
\hline 10 & Bank of Baroda & 45 & 10 & 450 \\
\hline 11 & Bank of India & 24 & 10 & 240 \\
\hline 12 & Bank of Maharashtra & 47 & 10 & 470 \\
\hline 13 & Canara Bank & 24 & 10 & 240 \\
\hline 14 & Central Bank of India & 31 & 10 & 310 \\
\hline 15 & Corporation Bank & 17 & 10 & 170 \\
\hline 16 & Dena Bank & 38 & 10 & 380 \\
\hline 17 & Indian Bank & 49 & 10 & 490 \\
\hline 18 & Indian Overseas Bank & 36 & 10 & 360 \\
\hline 19 & Oriental Bank of Commerce & 6 & 10 & 60 \\
\hline 20 & Punjab \& Sind Bank & 43 & 10 & 430 \\
\hline 21 & Punjab National Bank & 65 & 10 & 650 \\
\hline 22 & Syndicate Bank & 22 & 10 & 220 \\
\hline 23 & UCO Bank & & & \\
\hline & & & & \\
\hline
\end{tabular}




\begin{tabular}{|c|c|c|c|c|}
\hline $\mathrm{SN}$ & Name of Bank & No. of & Assumed no. of & Total no. \\
\hline & & branches & employees per branch & of employees \\
\hline 24 & Union Bank of India & 30 & 10 & 300 \\
\hline 25 & United Bank of India & 9 & 10 & 90 \\
\hline 26 & Vijaya Bank & 45 & 10 & 450 \\
\hline 27 & IDBI Bank & 23 & 10 & 230 \\
\hline 28 & Bharatiya Mahila Bank & 1 & 10 & 10 \\
\hline 29 & Axis Bank & 47 & 10 & 470 \\
\hline 30 & Catholic Syrian Bank & 2 & 10 & 20 \\
\hline 31 & City Union Bank & 4 & 10 & 40 \\
\hline 32 & Dhanlaxmi Bank & 3 & 10 & 30 \\
\hline 33 & Federal Bank & 14 & 10 & 140 \\
\hline 34 & HDFC Bank & 78 & 10 & 780 \\
\hline 35 & ICICI Bank & 69 & 10 & 690 \\
\hline 36 & IDFC Bank & 1 & 10 & 10 \\
\hline 37 & IndusInd Bank & 15 & 10 & 150 \\
\hline 38 & ING Vysya Bank & 38 & 10 & 380 \\
\hline 39 & Karnataka Bank & 13 & 10 & 130 \\
\hline 40 & Karur Vysya Bank & 30 & 10 & 300 \\
\hline 41 & Kotak Mahindra Bank & 32 & 10 & 320 \\
\hline 42 & The Lakshmi Vilas Bank & 17 & 10 & 170 \\
\hline 43 & South Indian Bank & 33 & 10 & 330 \\
\hline 44 & Yes Bank & 24 & 10 & 240 \\
\hline 45 & Development Credit Bank Ltd. & 7 & 10 & 70 \\
\hline 46 & Bandhan Bank Ltd. & 2 & 10 & 20 \\
\hline 47 & RBL Bank Ltd & 2 & 10 & 20 \\
\hline 48 & The Jammu and Kashmir Bank & 3 & 10 & 30 \\
\hline 49 & Bank of Bahrain and Kuwait & 1 & 10 & 10 \\
\hline 50 & Bank of Nova Scotia & 1 & 10 & 10 \\
\hline 51 & BNP Paribas & 1 & 10 & 10 \\
\hline 52 & HSBC & 1 & 10 & 10 \\
\hline 53 & Standard Chartered Bank & 3 & 10 & 30 \\
\hline 54 & Citibank & 1 & 10 & 10 \\
\hline \multirow[t]{2}{*}{55} & Shinhan Bank & 1 & 10 & 10 \\
\hline & Total & 1572 & & 15720 \\
\hline
\end{tabular}

\section{Sample Framework}

The following details are extracted on top performing commercial banks including public sector, private sector and foreign banks in India during the year 2018-19:

\begin{tabular}{|c|l|l|l|}
\hline \multicolumn{5}{|c|}{ Top Performing Banks in the year 2018-2019 } \\
\hline Sr. No. & \multicolumn{1}{|c|}{ Top 15 public } & Top 10 Indian Banks & \multicolumn{1}{|c|}{ Top 15 private / } \\
\hline & commercial banks in India & & foreign banks in India \\
\hline 1 & SBI & BOB & HDFC \\
\hline 2 & PNB & HDFC Bank & ICICI \\
\hline 3 & BOB & Axis Bank & Axis Bank \\
\hline 4 & IDBI & Yes Bank & Kotak Mahindra \\
\hline 5 & Syndicate Bank & SBH & Yes Bank \\
\hline 6 & BOI & PNB & ING Vysya \\
\hline
\end{tabular}




\begin{tabular}{|c|l|l|l|}
\hline 7 & Canara Bank & Canara Bank & Indusind Bank \\
\hline 8 & Union Bank of India & Andhra Bank & Dhanalakshmi Bank \\
\hline 9 & Corporation Bank & Corporation Bank & Federal Bank \\
\hline 10 & Allahbad Bank & Indian Bank & Jummu \& Kashmir Bank \\
\hline 11 & Bank of Maharastra & & Lakshmi Vilas Bank \\
\hline 12 & Indian Oveseas Bank & & Ratnakar Bank \\
\hline 13 & Oriental Bank of Commerce & HSBC Bank \\
\hline 14 & Central Bank of India & Bank of America \\
\hline 15 & Dena Bank & Deutches Bank \\
\hline Source : http://companiesinindia.in; www.zeenews.india.com; www.indiaranker.com \\
\hline
\end{tabular}

\section{Data Analysis and Interpretation}

\subsection{SQM: Public Sector Banks (SQM PSB).}

5.1.1. Reliability Coefficient. The overall Cronbach's alpha of the data for responses from PSBs' customers is 0.969 which is very high.

5.1.2. Correlation Analysis (Table II). Correlation among the eight factors was checked. There is a low degree to a high degree of positive correlation (Karl Person's Correlation Coefficient values between 0.435 and 0.826 ) between the eight factors. This means that the factors are related and interdependent.

\begin{tabular}{|c|c|c|c|c|c|c|c|c|}
\hline \multicolumn{7}{|c|}{ Table II: Correlation Between Factor Mean (SQM_PSB) } \\
\hline & F1mean & F2mean & F3mean & F4mean & F5mean & F6mean & F7mean & F8mean \\
\hline F1mean & 1.000 & & & & & & & \\
\hline F2mean & 0.539 & 1.000 & & & & & & \\
\hline F3mean & 0.635 & 0.742 & 1.000 & & & & & \\
\hline F4mean & 0.568 & 0.675 & 0.824 & 1.000 & & & & \\
\hline F5mean & 0.553 & 0.603 & 0.740 & 0.682 & 1.000 & & & \\
\hline F6mean & 0.648 & 0.695 & 0.713 & 0.711 & 0.667 & 1.000 & & \\
\hline F7mean & 0.679 & 0.737 & 0.745 & 0.683 & 0.826 & 0.805 & 1.000 & \\
\hline F8mean & 0.435 & 0.468 & 0.548 & 0.508 & 0.528 & 0.640 & 0.529 & 1.000 \\
\hline \multicolumn{78}{|c|}{ Correlation is significant at 0.05 level } \\
\hline
\end{tabular}

5.1.3. Factor Analysis (Table III - at the end of the article). Using the PCA extraction method with Varimax rotation on the basic category level, 12 factors defining 55 service attributes have been extracted which explains $76.22 \%$ of the total variance in the responses on service quality. These extracted factors are labelled as: (i) behaviour and attitude of bank staff, (ii) bank charges, (iii) net-banking and mobile banking, (iv) reliability, (v) customer-oriented services, (vi) tangibles, (vii) ATM services, (viii) ambience, (ix) physical layout, (x) service delivery, (xi) convenience, and (xii) credibility. Cronbach's alpha for 11 of the 12 extracted factors lie between 0.808 and 0.982 indicating high internal reliability of the scales for each of these 11 factors. Factor 8: Ambience is dropped due to the inability of calculating Cronbach's alpha.

\subsection{SQM: Private Sector Banks (SQM_PvtSB).}

5.2.1. Reliability Coefficient. The overall Cronbach's alpha of the data for responses from PvtSB' customers is 0.977 which is very high.

5.2.2. Correlation Analysis (Table IV). Correlation among the eight factors was checked. There is low degree to high degree of positive correlation (Karl Person's Correlation Coefficient values between 0.354 and 0.933 ) between the eight factors. This means that the factors are related and interdependent. 


\begin{tabular}{|c|c|c|c|c|c|c|c|c|}
\hline \multicolumn{7}{|c|}{ Table IV: Correlation Between Factor Mean (SQM_PvtSB) } \\
\hline & F1mean & F2mean & F3mean & F4mean & F5mean & F6mean & F7mean & F8mean \\
\hline F1mean & 1 & & & & & & & \\
\hline F2mean & 0.629 & 1 & & & & & & \\
\hline F3mean & 0.496 & 0.736 & 1 & & & & & \\
\hline F4mean & 0.498 & 0.816 & 0.916 & 1 & & & & \\
\hline F5mean & 0.526 & 0.692 & 0.813 & 0.797 & 1 & & & \\
\hline F6mean & 0.562 & 0.733 & 0.677 & 0.758 & 0.785 & 1 & & \\
\hline F7mean & 0.652 & 0.766 & 0.778 & 0.769 & 0.933 & 0.839 & 1 & \\
\hline F8mean & 0.354 & 0.517 & 0.494 & 0.592 & 0.574 & 0.771 & 0.549 & 1 \\
\hline \multicolumn{8}{|c|}{ Correlation is significant at 0.05 level } \\
\hline
\end{tabular}

5.2.3. Factor Analysis (Table $V$ - at the end of the article). Using the PCA extraction method with Varimax rotation on the basic category level, 11 factors explaining 48 service attributes have been extracted which explains $85.68 \%$ of the total variance in the responses on service quality. These extracted factors are labelled as: (i) behaviour and attitude of bank staff, (ii) bank charges, (iii) reliable service delivery, (iv) net-banking and mobile banking, (v) ATM services, (vi) service products, (vii) physical environment and social responsibility, (viii) service ethics, (ix) tangible, (x) other service products, and (xi) physical layout and convenience. Cronbach's alpha for 10 of the 11 extracted factors lies between 0.806 and 0.976 indicating high internal reliability of the scales for each of these 10 factors. Factor 11: physical layout and convenience is dropped due to unreliable Cronbach's alpha (0.681).

\subsection{SQM: Foreign Banks (SQM_FB).}

5.3.1. Reliability Coefficient. The overall Cronbach's alpha of the data for responses from Foreign Banks' customers is 0.927 which is very high.

5.3.2. Correlation Analysis (Table VI). Correlation among the eight factors was checked. There is a low degree to a high degree of positive correlation (Karl Person's Correlation Coefficient values between 0.187 and 0.670 ) between the eight factors. This means that the factors are related and interdependent.

\begin{tabular}{|c|c|c|c|c|c|c|c|c|}
\hline \multicolumn{7}{|c|}{ Table VI: Correlation Between Factor Mean (SQM_FB) } \\
\hline & MeanF1 & MeanF2 & MeanF3 & MeanF4 & MeanF5 & MeanF6 & MeanF7 & MeanF8 \\
\hline MeanF1 & 1 & & & & & & & \\
\hline MeanF2 & 0.325 & 1 & & & & & & \\
\hline MeanF3 & 0.268 & 0.573 & 1 & & & & & \\
\hline MeanF4 & 0.554 & 0.501 & 0.547 & 1 & & & & \\
\hline MeanF5 & 0.420 & 0.527 & 0.497 & 0.542 & 1 & & & \\
\hline MeanF6 & 0.416 & 0.222 & 0.247 & 0.477 & 0.335 & 1 & & \\
\hline MeanF7 & 0.356 & 0.444 & 0.579 & 0.475 & 0.670 & 0.411 & 1 & \\
\hline MeanF8 & 0.317 & 0.076 & 0.050 & 0.218 & 0.195 & 0.423 & 0.187 & 1 \\
\hline \multicolumn{78}{|c|}{ Correlation is significant at 0.05 level } \\
\hline
\end{tabular}

5.3.3. Factor Analysis (Table VII - at the end of the article). Using the PCA extraction method with Varimax rotation on the basic category level, 18 factors explaining 54 service attributes have been extracted which explains $81.76 \%$ of the total variance in the responses on service quality. These extracted factors are labelled as: (i) bank charges, (ii) reliability, (iii) netbanking and mobile-banking, (iv) social responsibility, (v) service outcomes, (vi) behaviour and attitude of bank staff, (vii) service delivery, (viii) operational speed, (ix) tangibles, (x) service products, (xi) physical layout, (xii) convenience, (xiii) receptivity, (xiv) availability, (xv) equity, (xvi) credibility, (xvii) communication and (xviii) ATM services. Cronbach's alpha for 10 of the 11 extracted factors lies between 0.806 and 0.976 indicating high internal reliability of the 
scales for each of these 10 factors. Factor 11: physical layout and convenience is dropped due to unreliable Cronbach's alpha (0.681).

Factors "F8: Operational Speed", "F11: Physical Layout", "F13: Receptivity", "F14: Availability \& Willingness", "F15: Equity", "F16: Credibility", "F17: Communication", and "F18: ATM Service" are dropped from the analysis as the Cronbach's Alpha values of these factors are below 0.7 which means unreliability of scale. However, the factor loadings of 11 service attributes defined under these factors are above 0.6 which shows that there is a linear relationship between the service attributes and their respective factors. Cronbach's alpha for 10 factors of the 18 extracted factors lies between 0.716 and 0.987 indicating high internal reliability of the scales for each of these 10 factors.

\section{Research Findings}

Comparing the working model along with the original model obtained using literature review of the secondary research for SQM _ PSB, SQM _ PvtSB and SQM_FB (Table VIII, IX, X), reveals that there is a close similarity between the hypothesized model (derived from literature review) and the emerging model based on factor analysis. The below table summarises the research findings.

The above table reflects the findings of the study with the following results.

\begin{tabular}{|c|c|c|c|}
\hline \multicolumn{2}{|c|}{$\begin{array}{l}\text { Table VIII: Comparison of SQM Dimensions in } \\
\text { SQM Dimensions Generated from Factor } \\
\text { Analysis }\end{array}$} & \multicolumn{2}{|c|}{$\begin{array}{l}\text { SQM Dimensions based on Secondary Re- } \\
\text { search for General Service Sector }\end{array}$} \\
\hline Factor & Factor Name & Factor & Factor Name \\
\hline \multirow[t]{5}{*}{ Factor1 } & $\begin{array}{l}\text { Behaviour and Attitude of } \\
\text { Bank Staff }\end{array}$ & Factor2 & Reliability \\
\hline & & Factor3 & Responsiveness \\
\hline & & Factor 4 & Assurance \\
\hline & & Factor5 & Empathy \\
\hline & & Factor7 & Service Delivery \\
\hline Factor2 & Bank Charges & Factor8 & Social Responsibility \\
\hline \multirow[t]{2}{*}{ Factor3 } & $\begin{array}{l}\text { Net-Banking and Mobile } \\
\text { Banking }\end{array}$ & Factor5 & Empathy \\
\hline & & Factor7 & Service Delivery \\
\hline \multirow[t]{2}{*}{ Factor 4} & Reliability & Factor2 & Reliability \\
\hline & & Factor7 & Service Delivery \\
\hline \multirow[t]{3}{*}{ Factor5 } & $\begin{array}{l}\text { Customer Oriented Service } \\
\text { Outcomes }\end{array}$ & Factor5 & Empathy \\
\hline & & Factor6 & Service Product \\
\hline & & Factor8 & Social Responsibility \\
\hline Factor6 & Tangibles & Factor1 & Tangibles \\
\hline \multirow[t]{3}{*}{ Factor7 } & ATM Service & Factor 1 & Tangibles \\
\hline & & Factor3 & Responsiveness \\
\hline & & Factor7 & Service Delivery \\
\hline Factor8* & Ambience & & \\
\hline Factor9 & Physical Layout & Factor1 & Tangibles \\
\hline \multirow[t]{2}{*}{ Factor10 } & Service Delivery & Factor6 & Service Product \\
\hline & & Factor7 & Service Delivery \\
\hline Factor $11^{* *}$ & Convenience & & \\
\hline \multirow[t]{2}{*}{ Factor12 } & Credibility & Factor2 & Reliability \\
\hline & & Factor7 & Service Delivery \\
\hline
\end{tabular}


6.1. Public Sector Banks. The emergence of principal factors like "Bank Charges", "NetBanking and Mobile-Banking" and "ATM Services" which were earlier latent in "Social Responsibility" and "Service Delivery" respectively with bigger coverage. Similarly, "Customer Oriented Service Outcome" has also emerged as a separate factor combining service attributes of original factors "Service Product" and "Social Responsibility". On the other hand, "Behaviour and Attitude of Bank Staff" has emerged as a single factor combining human aspects of "Reliability, Responsiveness, Assurance, Empathy, and Service Delivery".

\begin{tabular}{|c|c|c|c|}
\hline \multicolumn{2}{|c|}{$\begin{array}{l}\text { Table IX: Comparison of SQM Dimensions in F } \\
\text { SQM Dimensions Generate from Factor } \\
\text { Analysis }\end{array}$} & \multicolumn{2}{|c|}{$\begin{array}{l}\text { SQM Dimensions based on Secondary Re- } \\
\text { search for General Service Sector }\end{array}$} \\
\hline Factor & Factor Name & Factor & Factor Name \\
\hline \multirow[t]{5}{*}{ Factor 1} & $\begin{array}{l}\text { Behaviour and Attitude of } \\
\text { Bank Staff }\end{array}$ & Factor2 & Reliability \\
\hline & & Factor3 & Responsiveness \\
\hline & & Factor4 & Assurance \\
\hline & & Factor5 & Empathy \\
\hline & & Factor7 & Service Delivery \\
\hline Factor 2 & Bank Charges & Factor8 & Social Responsibility \\
\hline \multirow[t]{3}{*}{ Factor3 } & Reliable Service Delivery & Factor2 & Reliability \\
\hline & & Factor4 & Assurance \\
\hline & & Factor7 & Service Delivery \\
\hline \multirow[t]{2}{*}{ Factor 4} & $\begin{array}{l}\text { Net-Banking and Mobile- } \\
\text { Banking }\end{array}$ & Factor5 & Empathy \\
\hline & & Factor7 & Service Delivery \\
\hline \multirow[t]{3}{*}{ Factor5 } & ATM Service & Factor1 & Tangibles \\
\hline & & Factor2 & Responsiveness \\
\hline & & Factor7 & Service Delivery \\
\hline Factor6 & Service Product & Factor6 & Service Product \\
\hline Factor $7^{*}$ & $\begin{array}{l}\text { Physical Environment and } \\
\text { Social Responsibility }\end{array}$ & & \\
\hline Factor8 & Service Ethics & Factor8 & Social Responsibility \\
\hline Factor9 & Tangibles & Factor1 & Tangibles \\
\hline Factor $10^{*}$ & Other Service Product & & \\
\hline Factor $11^{* *}$ & $\begin{array}{l}\text { Physical Layout and Con- } \\
\text { venience }\end{array}$ & & \\
\hline
\end{tabular}

6.2. Private Sector Banks. The emergence of principal factors like "Bank Charges", "NetBanking and Mobile-Banking" and "ATM Services" which were earlier latent in "Social Responsibility" and "Service Delivery" respectively with wider coverage. Whereas, "Behaviour and Attitude of Bank Staff" have emerged as a single factor combining human aspects of "Reliability, Responsiveness, Assurance, Empathy, and Service Delivery". Likewise, private sector customers have evaluated "Reliable Service Delivery" as one factor combining "Reliability" and "Assurance" and service delivery.

6.3. Foreign Banks. The emergence of principal factors like "Bank Charges", "Net-Banking, and Mobile-Banking" which were earlier latent in "Social Responsibility" and "Service Delivery" respectively with broader coverage. However, "Behaviour and Attitude of Bank Staff" has emerged as a single factor combining human aspects of "Reliability, Responsiveness, Assurance, and Empathy. 


\begin{tabular}{|c|c|c|c|}
\hline $\begin{array}{l}\text { SQM Dimensions } \\
\text { Analysis }\end{array}$ & Generated from Factor & \multicolumn{2}{|c|}{$\begin{array}{l}\text { SQM Dimensions based on Secondary Re- } \\
\text { search for General Service Sector }\end{array}$} \\
\hline Factor & Factor Name & Factor & Factor Name \\
\hline Factor1 & Bank Charges & Factor8 & Social Responsibility \\
\hline Factor2 & Reliability & Factor4 & Reliability \\
\hline & & Factor7 & Service Delivery \\
\hline Factor3 & $\begin{array}{l}\text { Net-Banking and Mobile } \\
\text { Banking }\end{array}$ & Factor5 & Empathy \\
\hline & & Factor7 & Service Delivery \\
\hline Factor 4 & Social Responsibility & Factor5 & Empathy \\
\hline & & Factor8 & Social Responsibility \\
\hline Factor5 & Service Outcome & Factor6 & Service Product \\
\hline & & Factor7 & Service Delivery \\
\hline Factor6 & $\begin{array}{l}\text { Behaviour and Attitude of } \\
\text { Bank Staff }\end{array}$ & Factor2 & Reliability \\
\hline & & Factor3 & Responsiveness \\
\hline & & Factor4 & Assurance \\
\hline & & Factor5 & Empathy \\
\hline Factor7 & Service Delivery & Factor7 & Service Delivery \\
\hline Factor8* & Operational Speed & & \\
\hline Factor9 & Tangibles & Factor1 & Tangibles \\
\hline Factor10 & Service Product & Factor6 & Service Product \\
\hline Factor $11^{*}$ & Physical Layout & & \\
\hline Factor12 & Convenience & Factor1 & Tangibles \\
\hline Factor $13^{*}$ & Receptivity & & \\
\hline Factor $14^{*}$ & Availability & & \\
\hline Factor $15^{*}$ & Equity & & \\
\hline Factor $16^{*}$ & Credibility & & \\
\hline Factor $17^{*}$ & Communication & & \\
\hline Factor $18^{*}$ & ATM Service & & \\
\hline
\end{tabular}

6.4. Conclusion. We can conclude that the hypothesized model of Service Quality based on secondary research is adequate to derive specific SQM for Public, Private and Foreign Banks in India. The research work can be used as a reference guide by different sets of banks to implement quality practices within the individual constraints and requirements of the environment. The study highlights the importance of quantifying service quality and attempt to quantify certain aspects of service quality. This is because what is measurable can be easily compared and better understood. This study can form a base for researchers, academicians, and practitioners for further advanced studies in Banking Sector as well as other Financial Sectors.

\section{REFERENCES}

[1] Angur, M. G., Nataraajan, R. \& Jahera, J. S. (1999), Service quality in the banking industry: an assessment in a developing economy, International Journal of Bank Marketing 17: 116-23.

[2] Asubonteng, P., McCleary, K.J. \& Swan, J.E. (1996). SERVQUAL revisited: a critical review of service quality, The Journal of Services Marketing 10(6): 62-81.

[3] Chingang Nde Daniel \& Lukong Paul Berinyu (2010), Using the SERVQUAL Model to assess Service Quality and Customer Satisfaction: An Empirical study of grocery stores in Umea, Spring semester, 2010, Master thesis, one-year, Umea University.

[4] Elango, R. \& Gudep, V. K., (2006), A Comparative Study on the Service Quality and Customers Satisfaction among Private, Public and Foreign banks, The ICFAI Journal of Management 5(3): 8-19. 
[5] Joseph M, Stone G (2003), An empirical evaluation of US bank customer perceptions of the impact of technology on service delivery in banking sector, International Journal of Retail and Distribution Management 31: 190-202.

[6] Kayis B, Kim H, Shin TH (2003), A comparative analysis of cultural, conceptual and practical constraints on quality management implementations-findings from Australian and Korean banking industries, Total Quality Management \& Business Excellence 14: 765-777.

[7] Levin Richard I \& Rubin David S (1998), Statistics for Management, Seventh Edition, Prentice-Hall India.

[8] Parasuraman A., Zeithaml, V. A., \& Berry, L. L. (1988), SERVQUAL: A multiple-item scale for measuring consumer perceptions of service quality, Journal of Retailing 64(1): 12-40.

[9] Sabrina Tazreen (2012), An Empirical Study of Servqual as a Tool for Service Quality Measurement, IOSR Journal of Business and Management 1(5): 09-19.

[10] Sahin, B., Demir, C., Celik, Y., \& Teke, A. K. (2006), Factors affecting satisfaction level with the food services in a military hospital, Journal of medical systems 30(5): 381-387.

[11] Saravanan, R. \& Rao, K. S. P. (2007), Measurement of service quality from the customer's perspective An empirical study, Total Quality Management 18(4): 435-449.

[12] Sathya Pal Sharma N. K. and Prasad H.L (2014), Banking Development and Challenges, International Journal of Advancements in Research \& Technology 3(11): 113-117.

[13] S. Santhana Jeyalakshmi and Dr. S. Meenakumar (2016), Service Quality Management: A Literature Review, Shanlax International Journal of Management 3(4): 22-45.

[14] W. Edwards Deming, (1986), Out of the Crisis, Cambridge, MA, Massachusetts Institute of Technology.

[15] Wang Y, Lo HP, Hui YV (2003), The antecedents of service quality and product quality and their influences on bank reputation: evidence from banking industry in China, Managing Service Quality 13: 72-83.

[16] Wicks, A. M., \& Roethlein, C. J. (2009), A Satisfaction-Based Definition of Quality, Journal of Business \& Economic Studies 15(1): 82-97.

[17] Zeithaml Valrie A, Parasuraman A \& Berry L.L., (1990), Delivering Quality Service - Balancing Customer Perceptions and Expectations, New York, The Free Press.

\section{List of Figures}

Fugure 1: Hypothesized Service Quality Management Model 


\begin{tabular}{|c|c|c|c|c|c|c|}
\hline & KMO & & o & & & \\
\hline \multirow[t]{2}{*}{ Factors } & Factor Name and $\%$ & Qn St & Service Attributes & Loadings & No. of Statements & Cronbach's Alpha \\
\hline & Variance Explained & & & & & \\
\hline \multirow[t]{10}{*}{ F 1} & $\begin{array}{l}\text { Behaviour and Atti- } \\
\text { tude }\end{array}$ & 12 & $\begin{array}{l}\text { Interest in Solving Customer } \\
\text { Problems }\end{array}$ & 0.76 & 10 & 0.949 \\
\hline & of Bank Staff $(13.62 \%)$ & 16 & $\begin{array}{l}\text { Ability to Provide Prompt and } \\
\text { Timely Service eg. Speed of work }\end{array}$ & 0.76 & & \\
\hline & & 17 & $\begin{array}{l}\text { Availability of Bank Staff (Punc- } \\
\text { tuality) }\end{array}$ & 0.64 & & \\
\hline & & 18 & $\begin{array}{l}\text { Ability to explain processes \& } \\
\text { procedures, schemes, system, } \\
\text { banking operations, etc. }\end{array}$ & 0.77 & & \\
\hline & & 20 & Communication with customers & 0.79 & & \\
\hline & & 21 & $\begin{array}{l}\text { Possession of the required skills } \\
\text { and knowledge eg. Awareness of } \\
\text { new schemes, rules, interest rates, } \\
\text { etc. }\end{array}$ & 0.69 & & \\
\hline & & 22 & $\begin{array}{l}\text { Ability to Gain Customer's Trust. } \\
\text { Bank employees' efforts to con- } \\
\text { vince the customers satisfactory }\end{array}$ & 0.79 & & \\
\hline & & 24 & $\begin{array}{l}\text { Bank Staff's caring, individual- } \\
\text { ized attention on customers' en- } \\
\text { quiries }\end{array}$ & 0.78 & & \\
\hline & & 28 & $\begin{array}{l}\text { Intensity of work of the banks } \\
\text { staff }\end{array}$ & 0.77 & & \\
\hline & & 52 & $\begin{array}{l}\text { Extent to which the feedback from } \\
\text { customers is used to improve ser- } \\
\text { vice standard i.e. Willingness for } \\
\text { improvement }\end{array}$ & 0.79 & & \\
\hline \multirow[t]{11}{*}{ F 2} & $\begin{array}{l}\text { Bank } \quad \text { Charges } \\
(12.57 \%)\end{array}$ & 55 & Bank Charges for A/C statement & 0.77 & 11 & 0.959 \\
\hline & & 56 & $\begin{array}{l}\text { Bank Charges for Transfer of fund } \\
\text { through RTGS, NEFT, etc. }\end{array}$ & 0.84 & & \\
\hline & & 57 & $\begin{array}{l}\text { Bank Charges for Debit Card } \\
\text { Charges }\end{array}$ & 0.87 & & \\
\hline & & 58 & $\begin{array}{l}\text { Bank Charges for Credit Card } \\
\text { Charges }\end{array}$ & 0.84 & & \\
\hline & & 59 & $\begin{array}{l}\text { Bank Charges for Withdrawal } \\
\text { from ATMs }\end{array}$ & 0.81 & & \\
\hline & & 60 & $\begin{array}{l}\text { Bank Charges for Cheque book } \\
\text { charges }\end{array}$ & 0.85 & & \\
\hline & & 61 & $\begin{array}{l}\text { Bank Charges for Stop payment } \\
\text { charges }\end{array}$ & 0.85 & & \\
\hline & & 62 & $\begin{array}{l}\text { Bank Charges for On-line trans- } \\
\text { actions (net-banking or mobile- } \\
\text { banking) }\end{array}$ & 0.82 & & \\
\hline & & 63 & Bank Charges for Locker charges & 0.75 & & \\
\hline & & 64 & $\begin{array}{l}\text { Bank Charges for Loan processing } \\
\text { charges }\end{array}$ & 0.74 & & \\
\hline & & 43 & Reasons specified for any query & 0.85 & & \\
\hline
\end{tabular}


PRINCIPAL FACTORS MEASURING SERVICE QUALITY

\begin{tabular}{|c|c|c|c|c|c|c|}
\hline \multirow[t]{8}{*}{ F3 } & $\begin{array}{l}\text { Net-Banking and } \\
\text { Mobile-Banking } \\
(9.68 \%)\end{array}$ & 45 & $\begin{array}{l}\text { Navigation in Net Banking \& } \\
\text { Mobile-Banking }\end{array}$ & 0.84 & 8 & 0.947 \\
\hline & & 46 & $\begin{array}{l}\text { Download speed in Net \& Mobile- } \\
\text { Banking }\end{array}$ & 0.81 & & \\
\hline & & 47 & $\begin{array}{l}\text { Server Support in Net \& Mobile- } \\
\text { Banking }\end{array}$ & 0.82 & & \\
\hline & & 48 & $\begin{array}{l}\text { Transaction Settlement Time in } \\
\text { Net Banking, Mobile-Banking, } \\
\text { RTGS, NEFT, etc. }\end{array}$ & 0.85 & & \\
\hline & & 25 & $\begin{array}{l}\text { Keeping customers' best interest } \\
\text { at heart by maintaining Privacy of } \\
\text { Transaction }\end{array}$ & 0.89 & & \\
\hline & & 26 & $\begin{array}{l}\text { Keeping customers' best interest } \\
\text { at heart by providing Security of } \\
\text { Transaction }\end{array}$ & 0.86 & & \\
\hline & & 49 & SMS Services & 0.68 & & \\
\hline & & 50 & Bank Mobile Application, if any & 0.61 & & \\
\hline Factors & $\begin{array}{l}\text { Factor Name and \% } \\
\text { Variance Explained }\end{array}$ & Qn St & Service Attributes & Loadings & No. of Statements & Cronbach's Alpha \\
\hline \multirow[t]{4}{*}{ F 4} & Reliability $(7.17 \%)$ & 14 & $\begin{array}{l}\text { Ability to Provide Error Free } \\
\text { A/C Statement, Interest State- } \\
\text { ment, etc. }\end{array}$ & 0.85 & 4 & 0.913 \\
\hline & & 15 & $\begin{array}{l}\text { Ability to Perform Services accu- } \\
\text { rately in providing any documents }\end{array}$ & 0.86 & & \\
\hline & & 37 & Maintenance of documents & 0.83 & & \\
\hline & & 38 & Accuracy of documentation & 0.84 & & \\
\hline \multirow[t]{8}{*}{ F 5} & $\begin{array}{ll}\text { Customer } & \text { Oriented } \\
\text { Service } & \text { Outcome } \\
(10.07 \%) & \\
\end{array}$ & 31 & Loan facility & 0.75 & 8 & 0.947 \\
\hline & & 32 & Locker facility & 0.78 & & \\
\hline & & 33 & $\begin{array}{l}\text { Bankassurance [Insurance offered } \\
\text { by Bank] }\end{array}$ & 0.81 & & \\
\hline & & 34 & $\begin{array}{l}\text { Investment Plans [FDs, RDs, Mu- } \\
\text { tual Funds, etc.] }\end{array}$ & 0.74 & & \\
\hline & & 35 & $\begin{array}{l}\text { Innovative services, if any [eg. } \\
\text { SIP] }\end{array}$ & 0.76 & & \\
\hline & & 27 & $\begin{array}{l}\text { Taking Customer Feedback on } \\
\text { regular interval }\end{array}$ & 0.60 & & \\
\hline & & 65 & Bank promotes ethical conduct & 0.61 & & \\
\hline & & 67 & Customer education programs & 0.60 & & \\
\hline \multirow[t]{2}{*}{ F 6} & Tangibles $(4.35 \%)$ & 2 & $\begin{array}{l}\text { Physical Facilities, Equipment, } \\
\text { etc. eg. Kiosk, Drop boxes, token } \\
\text { machine }\end{array}$ & 0.91 & 2 & 0.847 \\
\hline & & 11 & Proper Housekeeping & 0.91 & & \\
\hline \multirow[t]{4}{*}{ F 7} & ATM Service $(4.68 \%)$ & 6 & Security at ATMs & 0.73 & 4 & 0.829 \\
\hline & & 19 & $\begin{array}{l}\text { Willingness to help customers at } \\
\text { all time }\end{array}$ & 0.67 & & \\
\hline & & 44 & Operationality of ATMs & 0.73 & & \\
\hline & & 53 & Problem solving speed & 0.64 & & \\
\hline
\end{tabular}




\begin{tabular}{|c|c|c|c|c|c|c|}
\hline Factors & $\begin{array}{l}\text { Factor Name and \% } \\
\text { Variance Explained }\end{array}$ & Qn St & Service Attributes & Loadings & No. of Statements & Cronbach's Alpha \\
\hline $\mathrm{F} 8 *$ & Ambience $(2.47 \%)^{*}$ & 1 & $\begin{array}{l}\text { Visually appealing ambient condi- } \\
\text { tion like air conditioning, seating, } \\
\text { waiting areas etc. }\end{array}$ & 0.62 & 1 & \\
\hline \multirow[t]{2}{*}{ F 9} & $\begin{array}{l}\text { Physical Layout } \\
(3.56 \%)\end{array}$ & 4 & Security system inside the bank & 0.88 & 2 & 0.808 \\
\hline & & 10 & $\begin{array}{l}\text { Visually Appealing Written Mate- } \\
\text { rial inside the bank }\end{array}$ & 0.88 & & \\
\hline \multirow[t]{2}{*}{ F 10} & $\begin{array}{ll}\text { Service } & \text { Delivery } \\
(3.00 \%) & \end{array}$ & 40 & $\begin{array}{lll}\text { Clarity in } & \text { Documentation } \\
\text { Processes } & & \end{array}$ & 0.64 & 2 & 0.890 \\
\hline & & 29 & $\begin{array}{l}\text { Clarity of statements, Documents, } \\
\text { etc. }\end{array}$ & 0.64 & & \\
\hline $\mathrm{F} 11^{* *}$ & $\begin{array}{l}\text { Convenience } \\
(2.38 \%)^{* *}\end{array}$ & 8 & Convenience in parking area & 0.60 & 1 & 0.516 \\
\hline \multirow[t]{2}{*}{ F 12} & Credibility $(2.69 \%)$ & 13 & $\begin{array}{l}\text { Right Deliver of Service First time } \\
\text { and every time }\end{array}$ & 0.69 & 2 & 0.982 \\
\hline & & 41 & Standard of services & 0.68 & & \\
\hline & $*$ & ctor 8 & dropped after inability of calcula & g Cronbac & s Alpha & \\
\hline
\end{tabular}




\begin{tabular}{|c|c|c|c|c|c|c|}
\hline \multirow[b]{2}{*}{ Factors } & \multicolumn{2}{|l|}{ KMO } & \multirow{2}{*}{$\begin{array}{r}0.632 \\
\text { Service Attributes }\end{array}$} & \multirow[b]{2}{*}{ Loadings } & \multirow[b]{2}{*}{ No. of St } & \multirow[b]{2}{*}{ Cronbach's Alpha } \\
\hline & $\begin{array}{l}\text { Factor Name and } \\
\% \text { Variance Ex- } \\
\text { plained }\end{array}$ & Qn St & & & & \\
\hline \multirow[t]{10}{*}{ F1 } & $\begin{array}{l}\text { Behaviour and } \\
\text { Attitude of Bank } \\
\text { Staff }(16.57 \%)\end{array}$ & 12 & $\begin{array}{l}\text { Interest in Solving Customer } \\
\text { Problems }\end{array}$ & 0.88 & 10 & 0.976 \\
\hline & & 16 & $\begin{array}{l}\text { Ability to Provide Prompt and } \\
\text { Timely Service eg. Speed of work }\end{array}$ & 0.88 & & \\
\hline & & 17 & $\begin{array}{l}\text { Availability of Bank Staff i.e. } \\
\text { Punctuality }\end{array}$ & 0.78 & & \\
\hline & & 18 & $\begin{array}{l}\text { Ability to explain processes \& } \\
\text { procedures, schemes, system, } \\
\text { banking operations, etc. }\end{array}$ & 0.83 & & \\
\hline & & 20 & Communication with Customers & 0.87 & & \\
\hline & & 21 & $\begin{array}{l}\text { Possession of the required skills } \\
\text { and knowledge eg. Awareness of } \\
\text { new schemes, rules, interest rates, } \\
\text { etc. }\end{array}$ & 0.79 & & \\
\hline & & 22 & $\begin{array}{l}\text { Ability to Gain Customer's Trust. } \\
\text { Bank employees' efforts to con- } \\
\text { vince the customers satisfactory }\end{array}$ & 0.87 & & \\
\hline & & 24 & $\begin{array}{l}\text { Bank Staff's caring, individual- } \\
\text { ized attention on customers' en- } \\
\text { quiries }\end{array}$ & 0.81 & & \\
\hline & & 28 & intensity of work of the banks staff & 0.87 & & \\
\hline & & 52 & $\begin{array}{l}\text { Extent to which the feedback from } \\
\text { customers is used to improve ser- } \\
\text { vice standard i.e. Willingness of } \\
\text { improvement }\end{array}$ & 0.75 & & \\
\hline \multirow[t]{11}{*}{$\mathrm{F} 2$} & $\begin{array}{l}\text { Bank Charges } \\
(14.56 \%)\end{array}$ & 55 & Bank Charges for A/C statement & 0.75 & 11 & 0.958 \\
\hline & & 56 & $\begin{array}{l}\text { Bank Charges for Transfer of fund } \\
\text { through RTGS, NEFT, etc. }\end{array}$ & 0.89 & & \\
\hline & & 57 & $\begin{array}{l}\text { Bank Charges for Debit Card } \\
\text { Charges }\end{array}$ & 0.84 & & \\
\hline & & 58 & $\begin{array}{l}\text { Bank Charges for Credit Card } \\
\text { Charges }\end{array}$ & 0.80 & & \\
\hline & & 59 & $\begin{array}{l}\text { Bank Charges for Withdrawal } \\
\text { from ATMs }\end{array}$ & 0.85 & & \\
\hline & & 60 & $\begin{array}{l}\text { Bank Charges for Cheque book } \\
\text { charges }\end{array}$ & 0.89 & & \\
\hline & & 61 & $\begin{array}{l}\text { Bank Charges for Stop payment } \\
\text { charges }\end{array}$ & 0.85 & & \\
\hline & & 62 & $\begin{array}{l}\text { Bank Charges for On-line trans- } \\
\text { actions (net-banking or mobile- } \\
\text { banking) }\end{array}$ & 0.83 & & \\
\hline & & 63 & Bank Charges for Locker charges & 0.69 & & \\
\hline & & 64 & $\begin{array}{l}\text { Bank Charges for Loan processing } \\
\text { charges }\end{array}$ & 0.77 & & \\
\hline & & 43 & Reasons specified for any query & 0.80 & & \\
\hline
\end{tabular}




\begin{tabular}{|c|c|c|c|c|c|c|}
\hline Factors & $\begin{array}{l}\text { Factor Name and } \\
\% \text { Variance Ex- } \\
\text { plained }\end{array}$ & Qn St & Service Attributes & Loadings & No. of St & Cronbach's Alpha \\
\hline \multirow[t]{7}{*}{ F 3} & $\begin{array}{l}\text { Reliable Service } \\
\text { Delivery }(11.41 \%)\end{array}$ & 13 & $\begin{array}{l}\text { Right Delivery of Service First } \\
\text { time and every time }\end{array}$ & 0.67 & 7 & 0.960 \\
\hline & & 14 & $\begin{array}{l}\text { Ability to Provide Error Free } \\
\text { A/C Statement, Interest State- } \\
\text { ment, etc. }\end{array}$ & 0.89 & & \\
\hline & & 15 & $\begin{array}{l}\text { Ability to Perform Services accu- } \\
\text { rately in providing any documents }\end{array}$ & 0.88 & & \\
\hline & & 23 & $\begin{array}{l}\text { Ability of Bank Employees to han- } \\
\text { dle critical incident by having } \\
\text { close coordination }\end{array}$ & 0.60 & & \\
\hline & & 37 & Maintenance of documents & 0.89 & & \\
\hline & & 38 & Accuracy of documentation & 0.88 & & \\
\hline & & 41 & Maintaining Standard of services & 0.67 & & \\
\hline \multirow[t]{8}{*}{ F 4} & $\begin{array}{l}\text { Net-Banking and } \\
\text { Mobile-Banking } \\
(12.16 \%)\end{array}$ & 45 & $\begin{array}{l}\text { Navigation in Net Banking \& } \\
\text { Mobile-Banking }\end{array}$ & 0.87 & 8 & 0.971 \\
\hline & & 46 & $\begin{array}{l}\text { Download speed in Net Banking \& } \\
\text { Mobile-Banking }\end{array}$ & 0.87 & & \\
\hline & & 47 & $\begin{array}{l}\text { Server Support in Net Banking \& } \\
\text { Mobile-Banking }\end{array}$ & 0.85 & & \\
\hline & & 48 & $\begin{array}{l}\text { Transaction Settlement Time in } \\
\text { Net Banking, Mobile-Banking, } \\
\text { RTGS, NEFT, etc. }\end{array}$ & 0.86 & & \\
\hline & & 49 & SMS Services & 0.79 & & \\
\hline & & 50 & Bank Mobile Application, if any & 0.80 & & \\
\hline & & 25 & $\begin{array}{l}\text { Keeping customers' best interest } \\
\text { at heart by maintaining Privacy of } \\
\text { Transaction }\end{array}$ & 0.87 & & \\
\hline & & 26 & $\begin{array}{l}\text { Keeping customers' best interest } \\
\text { at heart by providing Security of } \\
\text { Transaction }\end{array}$ & 0.85 & & \\
\hline \multirow[t]{5}{*}{ F 5} & $\begin{array}{ll}\text { ATM } & \text { Service } \\
(7.65 \%) & \end{array}$ & 6 & Security at ATMs & 0.80 & 5 & 0.913 \\
\hline & & 9 & Convenience in Location of ATMs & 0.66 & & \\
\hline & & 19 & $\begin{array}{l}\text { Willingness to help customers at } \\
\text { all time }\end{array}$ & 0.64 & & \\
\hline & & 44 & Operationality of ATMs & 0.66 & & \\
\hline & & 53 & Problem solving speed & 0.67 & & \\
\hline \multirow[t]{2}{*}{ F 6} & $\begin{array}{ll}\text { Service } & \text { Product } \\
(4.94 \%) & \end{array}$ & 34 & $\begin{array}{l}\text { Investment Plans [FDs, RDs, Mu- } \\
\text { tual Funds, etc.] }\end{array}$ & 0.64 & 2 & 0.806 \\
\hline & & 35 & Operating hours of banks & 0.69 & & \\
\hline F 7 & $\begin{array}{l}\text { Physical Environ- } \\
\text { ment and Social } \\
\text { Responsibility } \\
(3.70 \%)^{*}\end{array}$ & & & & 6 & 0.825 \\
\hline
\end{tabular}




\begin{tabular}{|c|c|c|c|c|c|c|}
\hline Factors & $\begin{array}{l}\text { Factor Name and } \\
\% \text { Variance Ex- } \\
\text { plained }\end{array}$ & Qn St & Service Attributes & Loadings & No. of St & Cronbach's Alpha \\
\hline F8 & $\begin{array}{l}\text { Service } \\
(4.15 \%)\end{array}$ & 65 & Bank promotes ethical conduct & 0.85 & 1 & 0.870 \\
\hline \multirow[t]{2}{*}{ F9 } & Tangibles $(4.41 \%)$ & 2 & $\begin{array}{l}\text { Physical Facilities, Equipment, } \\
\text { etc. eg. Kiosk, Drop boxes, to- } \\
\text { ken machine }\end{array}$ & 0.88 & 2 & 0.814 \\
\hline & & 10 & Proper Housekeeping & 0.89 & & \\
\hline F10 & $\begin{array}{l}\text { Other Service } \\
\text { Product }(2.70 \%)^{*}\end{array}$ & & & & 2 & 0.823 \\
\hline \multirow[t]{2}{*}{ F 11} & $\begin{array}{l}\text { Physical Layout } \\
\text { and Convenience } \\
(3.44 \%)^{* *}\end{array}$ & 3 & No. of counters & 0.63 & 2 & 0.681 \\
\hline & & 7 & $\begin{array}{l}\text { Convenience in Location of } \\
\text { branches }\end{array}$ & 0.70 & & \\
\hline
\end{tabular}




\begin{tabular}{|c|c|c|c|c|c|c|}
\hline \multicolumn{7}{|c|}{ Table VII: Extracted Factor after Data Reduction using Varimax Rotation (SQM_FB) } \\
\hline & KMO & & 0.691 & & & \\
\hline Factors & $\begin{array}{l}\text { Factor Name and } \\
\% \text { Variance Ex- } \\
\text { plained }\end{array}$ & Qn St & Service Attributes & Loadings & No. of Statements & Cronbach's Alpha \\
\hline \multirow[t]{10}{*}{ F 1} & $\begin{array}{ll}\text { Bank } & \text { Charges } \\
(14.38 \%) & \\
\end{array}$ & 55 & $\begin{array}{l}\text { Bank Charges for } \mathrm{A} / \mathrm{C} \text { state- } \\
\text { ment }\end{array}$ & 0.63 & 10 & 0.987 \\
\hline & & 56 & $\begin{array}{l}\text { Bank Charges for Transfer of } \\
\text { fund through RTGS, NEFT, } \\
\text { etc. }\end{array}$ & 0.92 & & \\
\hline & & 57 & $\begin{array}{l}\text { Bank Charges for Debit Card } \\
\text { Charges }\end{array}$ & 0.95 & & \\
\hline & & 58 & $\begin{array}{l}\text { Bank Charges for Credit Card } \\
\text { Charges }\end{array}$ & 0.97 & & \\
\hline & & 59 & $\begin{array}{l}\text { Bank Charges for Withdrawal } \\
\text { from ATMs }\end{array}$ & 0.99 & & \\
\hline & & 60 & $\begin{array}{l}\text { Bank Charges for Cheque book } \\
\text { charges }\end{array}$ & 0.99 & & \\
\hline & & 61 & $\begin{array}{l}\text { Bank Charges for Stop payment } \\
\text { charges }\end{array}$ & 0.99 & & \\
\hline & & 62 & $\begin{array}{l}\text { Bank Charges for On-line trans- } \\
\text { actions (net-banking or mobile- } \\
\text { banking) }\end{array}$ & 0.95 & & \\
\hline & & 63 & $\begin{array}{l}\text { Bank Charges for Locker } \\
\text { charges }\end{array}$ & 0.99 & & \\
\hline & & 64 & $\begin{array}{l}\text { Bank Charges for Loan process- } \\
\text { ing charges }\end{array}$ & 0.99 & & \\
\hline \multirow[t]{4}{*}{$\mathrm{F} 2$} & $\begin{array}{l}\text { Reliability } \\
(5.47 \%)\end{array}$ & 14 & $\begin{array}{l}\text { Ability to Provide Error Free } \\
\text { A/C Statement, Interest State- } \\
\text { ment, etc. }\end{array}$ & 0.85 & 4 & 0.847 \\
\hline & & 15 & $\begin{array}{l}\text { A bility to Perform Services ac- } \\
\text { curately in providing any docu- } \\
\text { ments }\end{array}$ & 0.75 & & \\
\hline & & 37 & Maintenance of documents & 0.75 & & \\
\hline & & 38 & Accuracy of documentation & 0.62 & & \\
\hline \multirow[t]{8}{*}{ F 3} & $\begin{array}{l}\text { Net-Banking and } \\
\text { Mobile-Banking } \\
(10.34 \%) \\
\end{array}$ & 45 & $\begin{array}{l}\text { Navigation in Net Banking \& } \\
\text { Mobile-Banking }\end{array}$ & 0.88 & 8 & 0.960 \\
\hline & & 46 & $\begin{array}{l}\text { Download speed in Net Banking } \\
\text { \& Mobile-Banking }\end{array}$ & 0.94 & & \\
\hline & & 47 & $\begin{array}{l}\text { Server Support in Net Banking } \\
\& \text { Mobile-Banking }\end{array}$ & 0.92 & & \\
\hline & & 48 & $\begin{array}{l}\text { Transaction Settlement Time in } \\
\text { Net Banking, Mobile-Banking, } \\
\text { RTGS, NEFT, etc. }\end{array}$ & 0.93 & & \\
\hline & & 25 & $\begin{array}{l}\text { Keeping customers' best inter- } \\
\text { est at heart by maintaining Pri- } \\
\text { vacy of Transaction }\end{array}$ & 0.81 & & \\
\hline & & 26 & $\begin{array}{l}\text { Keeping customers' best inter- } \\
\text { est at heart by providing Secu- } \\
\text { rity of Transaction }\end{array}$ & 0.83 & & \\
\hline & & 49 & SMS Services & 0.84 & & \\
\hline & & 50 & Bank Mobile Application, if any & 0.79 & & \\
\hline
\end{tabular}




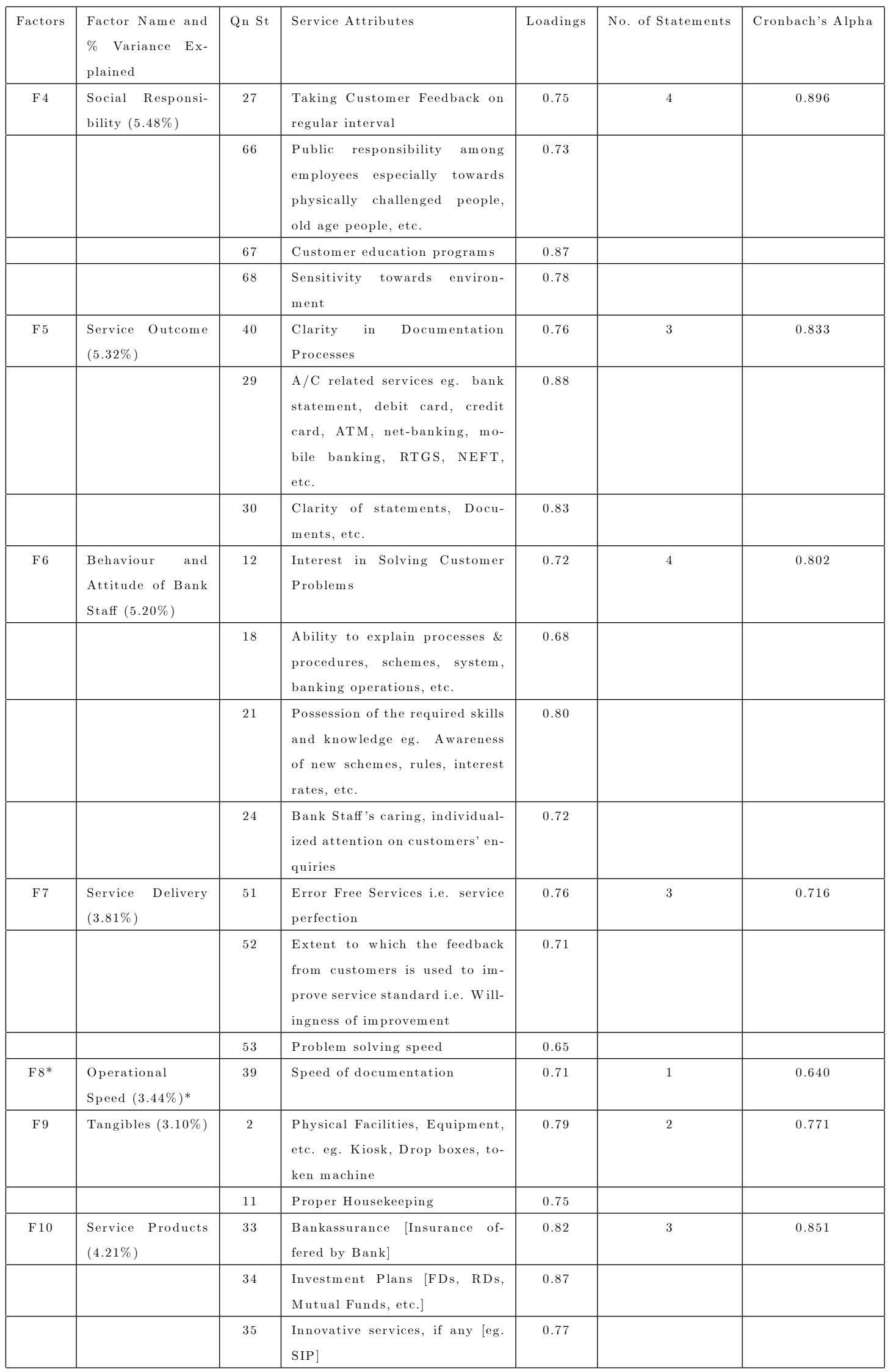




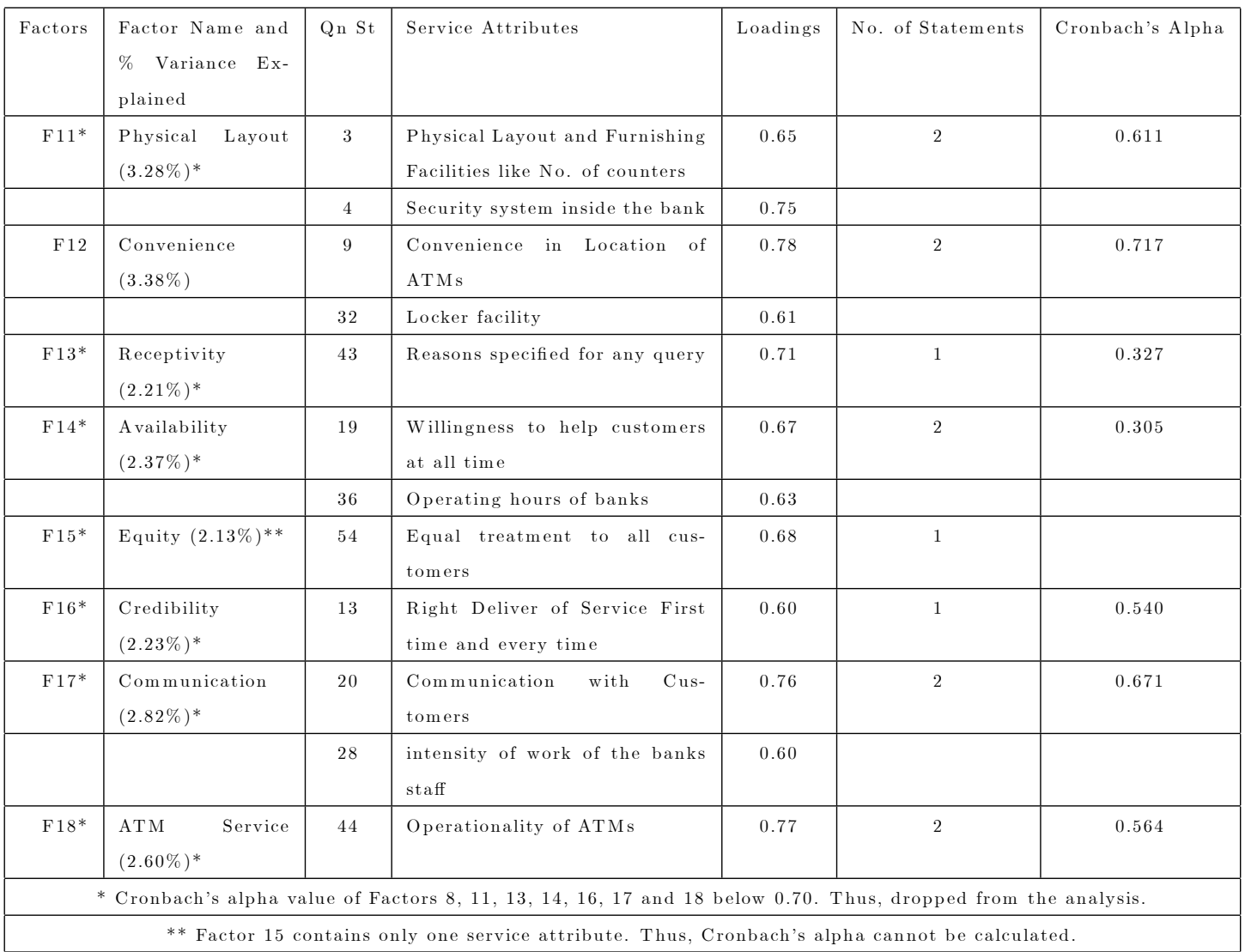

